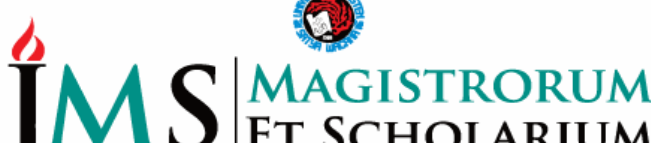 \\ - JURNAL PENGABDIAN MASYARAKAT
}

P-ISSN: 2722-9270 ejournal.uksw.edu/jms

\section{Pendampingan: Gereja Kristen Indonesia Tegalrejo dalam Menghadapi New Normal}

\author{
Putri Hergianasari* \\ Elisabeth Priscila Tamtalahitu \\ Aveliani Mega Elfrieda Sinaga \\ End Tresya Twanggin
}

Fakultas IImu Sosial dan IImu Komunikasi Universitas Kristen Satya Wacana

\section{Article history: \\ Received 08-01-2021 \\ Revised 11-01-2021 \\ Accepted 22-01-2021}

A R T I C L E I N F O

Key words:

The Covid-19 Pandemic, Clean and Healthy Living Behavior, Sustainable Development Goals SDGs)

\begin{abstract}
A B S T R A C T
The importance of this community activity is carried out to provide assistance to the Tegalrejo Indonesian Christian Church in facing the New Normal. The objectives, firstly to provide assistance to the church, second to socialize to the Indonesian Christian Church Tegalrejo congregation, especially Sunday School children applying Clean and Healthy Behavior in facing the New Normal. The method used is the making of a Clean and Healthy Behavior videos with church administrators, socialization to Sunday school children. The result of this community service is a Clean and Healthy Behavior video for Sunday School children, an increase in the capacity of church administrators in arranging procedures for conducting worship, increasing the capacity of Sunday school children in implementing Clean and Healthy Behavior in the New Normal era.
\end{abstract}

\section{A B S T R A K}

Pentingnya kegiatan masyarakat ini dilakukan untuk memberikan pendampingan kepada Gereja Kristen Indonesia Tegalrejo dalam menghadapi New Normal. Tujuan, pertama memberikan pendampingan kepada gereja, kedua mensosialisasikan kepada jemaat GKI Tegalrejo terutama anak-anak Sekolah Minggu penerapan Perilaku Hidup Bersih dan Sehat (PHBS) menghadapi New Normal. Metode yang digunakan adalah pembuatan video PHBS dengan pengurus Gereja, sosialisasi pada anak-anak Sekolah Minggu. Hasil dari pengabdian masyarakat ini adalah video PHBS untuk anak Sekolah Minggu, Peningkatan kapasitas pengurus gereja dalam menyusun tata cara pelaksanaan ibadah, peningkatan kapasitas anak-anak sekolah minggu dalam melaksanakan PHBS di era New Normal.

\footnotetext{
*Corresponding author: putri.hergianasari@uksw.edu
} 


\section{PENDAHULUAN}

Pandemi Covid-19 mengharuskan setiap orang untuk berdiam diri di rumah jika tidak ada kepentingan yang sangat mendesak agar penyebaran virus dapat terkendali, begitu pula dengan setiap gereja di kota Salatiga tepatnya Gereja Kristen Indonesia (GKI) Tegalrejo. Kondisi di Salatiga menunjukkan adanya peningkatanjumlah pasien Covid-19 Kota Salatiga (Humas Setda, 2020). Hal ini menjadikan gereja untuk dapat beradaptasi dengan keadaan New Normal. Gereja harus dapat mengambil langkah bijaksana dalam menghadapi era New Normal sehingga ibadah dapat terus berlangsung tanpa menyebabkan penambahan kasus Covid-19. Permasalahan dalam pengabdian masyarakat adalah GKI Tegalrejo belum mempunyai tata cara pelaksanaan ibadah dalam menghadapi New Normal, minimnya sosialisasi Perilaku Hidup Bersih dan Sehat (PHBS) pada anak-anak Sekolah Minggu. Pengabdian masyarakat dilakukan di GKI Tegalrejo karena Tegalrejo merupakan kelurahan di Kota Salatiga yang mempunyai kasus positif terbanyak yaitu 31 orang berdasarkan data Satgas Covid-19 Salatiga (Humas Setda, 2020).

Pentingnya pengabdian masyarakat dilakukan dengan tujuan yang pertama yaitu memberikan pendampingan dalam menyusun tata cara pelaksanaan ibadah New Normal agar ibadah GKI Tegalrejo dapat selalu berjalan. Kedua, pembuatan video Perilaku Hidup Bersih dan Sehat (PHBS) untuk anak Sekolah Minggu. Ketiga, mensosialisasikan Perilaku Hidup Bersih dan Sehat kepada anak-anak Sekolah Minggu melalui video pembelajaran yang mudah dipahami.

Konsep dan teori yang mendukung penyelesaian masalah dalam pengabdian masyarakat ini adalah konsep Sustainable Development Goals (SDGs) pada tujuan ke 3 terkait Good Health and Well Being. Pada SDGs tujuan 3 menjamin kehidupan yang sehat dan meningkatkan kesejahteraan seluruh penduduk semua usia. (SDGs, 2018) Kesehatan sendiri merupakan isu strategis pembangunan global terkhusus di tengah pandemi global yang muncul pada tahun 2019. Pembangunan kesehatan membutuhkan peran aktif seluruh pemangku kepentingan, mulai dari pemerintah pusat, pemerintah daerah, pemangku kepentingan, dan yang tidak kalah penting yaitu peran dari masyarakat dalam mewujudkan tercapainya pembangunan berkelanjutan pada bidang kesehatan.

Terdapat tiga pilar dalam mewujudkan program tujuan pembangunan berkelanjutan pada bidang kesehatan, yaitu paradigma sehat, jaminan kesehatan nasional dan pelayanan kesehatan. Pengabdian masyarakat ini menggunakan salah satu paradigma yaitu paradigma sehat yang mana merupakan sebuah pendekatan yang mengutamakan preventif dan promotif dalam menempatkan kesehatan sebagai bagian dari input proses pembangunan pada bidang kesehatan. SDGs dalam pelaksanaanya mengalami hambatan karena pandemi Covid-19, sehingga diharapkan dengan pengabdian masyarakat ini program pembangunan berkelanjutan pada bidang kesehatan setidaknya dapat terus berjalan melalui kesadaran individu-individu dalam menjalankan protokol kesehatan dan dalam menjalankan perilaku hidup bersih dan sehat.

Konsep Perilaku Hidup Bersih dan Sehat atau disingkat PHBS juga digunakan dalam menyelesaikan permasalahan pengabdian masyarakat. PHBS merupakan semua perilaku kesehatan yang dilakukan oleh karena kesadaran peribadi sehingga seluruh 
anggota keluarga dapat menolong diri sendiri pada bidang kesehatan dan memiliki peran aktif dalam aktivitas kesehatan baik di lingkungan keluarga maupun masyarakat. (Kemenkes, 2020) PHBS merupakan sebuah upaya dalam menularkan pengalaman untuk berperilaku bersih dan sehat baik invididu maupun kelompok dengan melalui media komunikasi dan informasi. Materi edukasi dapat dibagian melalui video, praktik langsung, pamflet serta media informasi lainnya. PHBS merupakan rekayasa sosial yang mempunyai tujuan menjadikan masyarakat sebagai agen perubahan untuk dapat meningkatkan kualitas perilaku kebersihan sehari-hari agar hidup sehat dan bersih.

Langkah-langkah PHBS yaitu dengan mengedukasi, memberikan pembinaan, pendampingan serta pemberdayaan masyarakat untuk dapat mengenal lingkungan sekitar dan mengetahui permasalahan kesehatan terutama pada tingkat pribadi dan rumah tangga sebagai langkah awal untuk memperbaiki pola dan gaya hidup. Manfaat dari PHBS adalah meningktkan kualitas hidup masyarakat melalui proses penyadaran, hal tersebut merupakan kontribusi dari individu-individu dalam menjalankan perilaku hidup yang bersih dan sehat. Sehingga terciptanya masyarakat yang sadar akan pentingnya kesehatan dan pola hidup yang sehat. Lima tatanan PHBS yang dapat digunakan untuk memulai proses penyadaran tentang perilaku hidup sehat antara lain PHBS di rumah tangga, PHBS di tempat kerja, PHBS di sekolah, PHBS di tempat umum dan PHBS di sarana kesehatan. Gereja merupakan PHBS tempat umum dan merupakan PHBS rumah tangga, karena jemaat merupakan kumpulan dari rumah tangga di dalamnya.

Salah satu indikator Perilaku Hidup Bersih dan Sehat pada tatanan rumah tangga adalah mencuci tangan dengan sabun dan air bersih. Hal tersebut merupakan praktik dari langkah hidup bersih sekaligus mencegah penularan dari berbagai macam jenis bakteri maupun virus yang menempel pada tangan, sehingga tangan menjadi bersih dan bebas dari bakteri dan virus. Hal tersebut juga merupakan salah satu langkah dalam protokol kesehatan di era New Normal.

Pandemik Covid-19 merupakan tantangan bagi penyelenggara Pilkada untuk dapat berinovasi sehingga pelaksanaan Pilkada tetap berlangsung tanpa muncul kasus positif dari pelaksanaan Pilkada 2020 tersebut. (Hergianasari, 2020). Hal tersebut juga dialami oleh Gereja-Gereja di Salatiga khususnya di GKI Tegalrejo dalam melaksanakan ibadah efektif dan tidak menyebabkan kasus positif Covid-19 bertambah. Inovasi dan kreativitas diperlukan dalam mengelola tata cara pelaksanaan ibadah era New Normal.

Peningkatan kesehatan untuk pencegahan covid-19 di gereja hkbp pagaran nauli resort medan millenium tahun 2020" dalam edukasi dan demontrasi terkait cuci tangan guna mencegah penyebaran Covid-19. (Sijabat et al., 2020). Artikel pada jurnal pengabdian masyarakat Maren: Jurnal Pengabdian dan Pemberdayaan Masyarakat Volume 1 No 2 Tahun 2020 yang berjudul "Produk Edukasi Cegah Covid-19 Hasil KKN PKM Daring UKIM di 3 Kabupaten/Kota di Maluku" juga melakukan pemahaman/pengetahuan dalam perilaku hidup bersih dan sehat. (Ukim, 2020). Perbedaan pengabdian masyarakat dengan judul "Electoral Distancing: Alternatif Penyelenggaraan Pemilihan Kepala Daerah 2020 ditengah Covid-19 di Indonesia" serta dengan judul "Produk Edukasi Cegah Covid-19 Hasil KKN PKM Daring UKIM di 3 Kabupaten/Kota di Maluku" dengan pengabdian masyarakat "Pendampingan: Gereja Kristen Indonesia Tegalrejo dalam Menghadapi New Normal” dilakukan 
secara luring dengan tetap memperhatikan protokol kesehatan Covid-19. Perbedaan pengabdian masyarakat dengan judul "Peningkatan Kesehatan untuk Pencegahan Covid-19 di Gereja HKBP Pagaran Nauli Resort Medan Millenium Tahun 2020" dengan pengabdian masyarakat dengan judul "Pendampingan: Gereja Kristen Indonesia Tegalrejo dalam Menghadapi New Normal" adalah menggunakan video pembelajaran PHBS berupa animasi yang mudah dimengerti anak-anak Sekolah Minggu.

\section{METODE PELAKSANAAN}

Pengabdian masyarakat merupakan salah satu program Pembelajaran Lapangan Terpadu pada Fakultas Ilmu Sosial dan Ilmu Komunikasi UKSW. Pengabdian masyarakat dilakukan secara luring pada saat Pandemi Covid-19 sedang berlangsung dengan menggunakan protokol kesehatan yang ketat. Dilaksanakan pada bulan Oktober-November 2020 yang berlokasi di Gereja Kristen Indonesia Tegalrejo Kota Salatiga. Metode dalam pengabdian masyarakat ini adalah dengan pendampingan pada pengurus gereja, sosialisasi dengan jemaat gereja, FGD serta brain storming dengan pengurus gereja GKI Tegalrejo.

Tahapan kegiatan yang dilakukan dalam pelaksanaan pengabdian masyarakat pertama mengidentifikasi permasalahan sekaligus kendala yang dihadapi GKI Tegalrejo dalam menghadai New Normal. Kedua mengidentifikasi tata cara pelaksanaan ibadah yang telah dilakukan saat Pandemi Covid-19. Ketiga melakukan brain storming dengan pengurus gereja untuk meningkatkan tata cara pelaksanaan ibadah yang lebih aman dan mudah diakses oleh seluruh jemaat. Keempat, meningkatkan dan menyusun tata cara pelaksanaan ibadah menghadapi New Normal. Kelima pembuatan video PHBS untuk anak Sekolah Minggu dengan melakukan pendamingan kepada pengurus gereja. Keenam sosialisasi video PHBS pada jemaat GKI Tegalrejo. Pengumpulan data dan informasi dilakukan secara lisan dan diskusi secara langsung dengan pihak-pihak lembaga gereja yang bersangkutan. Berikut merupakan tabel rencana kegiatan pengabdian masyarakat secara detail serta jadwal rencana kegiatan.

Tabel 1. Rencana Kegiatan Pengabdian Masyarakat

\begin{tabular}{lll}
\hline No & Jadwal Rutin Kegiatan Gereja & \multicolumn{1}{c}{ Rencana Pengabdian Masyarakat } \\
\hline 1 & $\begin{array}{l}\text { Pemahaman Alkitab setiap hari } \\
\text { Selasa dan Minggu secara daring }\end{array}$ & $\begin{array}{l}\text { Membantu melayani (pembuatan video, pembuatan } \\
\text { materi) gereja dalam persiapan, sewaktu acara Kegiatan } \\
\text { Pemahaman Alkitab } \\
\text { Ibadah Minggu secara offline } \\
\text { dalam skala terbatas }\end{array}$ \\
$\begin{array}{l}\text { Ibadah Minggu secara } \text { online } \\
\text { Sekolah Minggu } \text { online }\end{array}$ & $\begin{array}{l}\text { offline yang efektif dan efisien } \\
\text { Mendampingi pengurus gereja dalam pembuatan video } \\
\text { Mendampingi pengurus gereja dalam pembuatan video } \\
\text { PHBS dan Sosialisasi PHBS secara online }\end{array}$ \\
\hline
\end{tabular}

Tabel 2. Rencana Jadwal Pelaksanaan Kegiatan Pengabdian Masyarakat

\begin{tabular}{llllllllll}
\hline No & Kegiatan & \multicolumn{1}{c}{ Oktober } & \multicolumn{3}{c}{ November } \\
\hline & 1 & 2 & 3 & 4 & 1 & 2 & 3 & 4 \\
\hline
\end{tabular}




\begin{tabular}{|c|c|c|c|c|c|c|c|c|c|}
\hline 1 & Perkenalan, identifikasi masalah & V & & & & & & & \\
\hline 2 & $\begin{array}{l}\text { Pendampingan pembuatan Power Point } \\
\text { untuk tata Ibadah Minggu }\end{array}$ & & $\mathrm{V}$ & $\mathrm{V}$ & $\mathrm{V}$ & $\mathrm{V}$ & $\mathrm{V}$ & $\mathrm{V}$ & $\mathrm{v}$ \\
\hline 3 & $\begin{array}{l}\text { Pendampingan pengoprasian Power } \\
\text { Point pada Ibadah Minggu }\end{array}$ & & $\mathrm{V}$ & $\mathrm{V}$ & $\mathrm{V}$ & $\mathrm{V}$ & $\mathrm{V}$ & $\mathrm{V}$ & $\mathrm{v}$ \\
\hline 4 & $\begin{array}{l}\text { Pendampingan pengambilan video } \\
\text { pada Pemahaman Alkitab }\end{array}$ & & $\mathrm{V}$ & $\mathrm{V}$ & $\mathrm{V}$ & $\mathrm{V}$ & $\mathrm{V}$ & $\mathrm{V}$ & $\mathrm{V}$ \\
\hline 5 & Pengeditan video Pemahaman Alkitab & & $\mathrm{V}$ & $\mathrm{V}$ & $\mathrm{V}$ & $\mathrm{V}$ & $\mathrm{V}$ & $\mathrm{V}$ & $\mathrm{v}$ \\
\hline 6 & Pendampingan pengoperasian kamera & & $\mathrm{v}$ & $\mathrm{V}$ & $\mathrm{V}$ & $\mathrm{v}$ & $\mathrm{V}$ & $\mathrm{V}$ & $\mathrm{v}$ \\
\hline & saat live streaming & & & & & $\mathrm{v}$ & $\mathrm{V}$ & $\mathrm{v}$ & $\mathrm{v}$ \\
\hline 7 & Pembuatan Video PHBS & & & & & & & & $\mathrm{V}$ \\
\hline 8 & Sosialisasi Video PHBS secara daring & & & & & & & & \\
\hline
\end{tabular}

\section{HASIL DAN PEMBAHASAN}

Pengabdian masyarakat ini menghasilkan video Perilaku Hidup Bersih dan Sehat serta tata cara pelaksanaan Ibadah Minggu GKI Tegalrejo secara daring maupun luring yang mana menyempurnakan tata cara pelaksanaan ibadah yang telah dilakukan sebelumnya. Berikut merupakan tabel kegiatan pengabdian masyarakat yang telah dilakukan.

Tabel 3. Pendampingan yang Telah Dilakukan kepada GKI Tegalrejo untuk Menghadapi New Normal

\begin{tabular}{lll}
\hline No & Metode & \multicolumn{2}{c}{ Keterangan } \\
\hline 1 & Pendampingan & a. Penyusunan tata cara pelaksanaan ibadah New Normal luring \\
& & b. Penyempurnaan tata cara pelaksanaan ibadah daring \\
& c. Pembuatan video untuk kegiatan Pemahaman Alkitab \\
& d. Pembuatan materi untuk ibadah dan Pemahaman Alkitab \\
& Produksi & Pembuatan Video untuk PHBS anak Sekolah Minggu \\
3 & Sosialisasi & Bersama Guru Sekolah Minggu GKI Tegalrejo \\
& & mensosialisasikan video PHBS secara daring melalui \\
& & YouTube Channel GKI Tegalrejo \\
4 & Pelayanan & Membantu pembuatan video untuk Pemahaman Alkitab \\
\hline
\end{tabular}

Tata cara pelaksanaan ibadah yang telah dihasilkan dari pengabdian masyarakat ini adalah sebagai berikut: pertama, Gereja Kristen Indonesia di Tegalrejo saat Pandemi Covid-19 telah melakukan ibadah minggu secara daring yaitu dengan membagikan video yang telah diunggah di YouTube Channel dengan alamat Youtube GKI Tegalrejo Salatiga melalui What's App Group yang telah terbentuk.

Kedua, membantu pendampingan Kegiatan Pemahaman Alkitab dilaksanakan setiap hari Selasa dan Minggu secara daring. Tim pengabdian masyarakat dengan pihak gereja berkumpul pada hari Minggu sore untuk pengambilan video guna persiapan materi Pemahaman Alkitab pada hari Selasa. Setelah selesai mengadakan pengambilan video, tim pengabdian masyarakat melakukan pengeditan video di hari Senin, dan diunggah pada malam hari, paling lambat pagi hari pada hari Selasa sehingga siangnya link Pemahaman Alkitab GKI Tegalrejo sudah dapat dibagikan melalui Group What's App Info GKI Tegalrejo. Agenda dari kegiatan tersebut adalah jemaat dan pendeta bersama-sama berdiskusi mengenai perikop Alkitab yang telah ditentukan. Berikut merupakan gambar proses pengambilan video. 


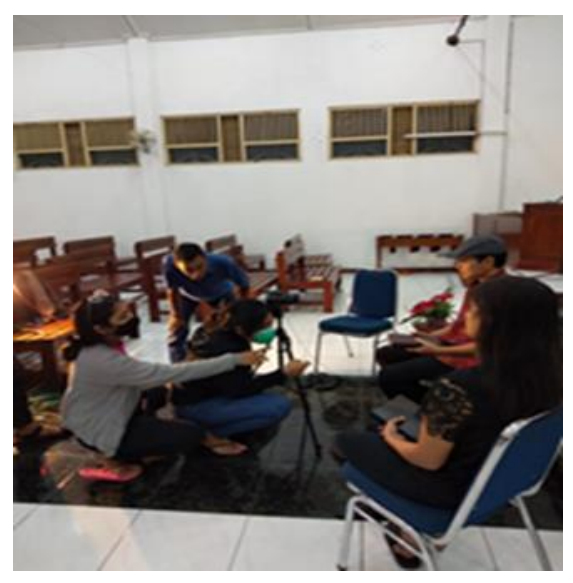

Gambar 1. Proses Pengambilan Video Pemahaman Alkitab

Ketiga, Ibadah mingguan di GKI Tegalrejo telah dilakukan secara offline juga dengan pembatasan kuota jemaat. Mengingat sebagian besar jemaat adalah orangorang tua yang sudah berumur sehingga lebih nyaman mengadakan ibadah secara offline. Beberapa pelayanan seperti pemain musik, kameramen untuk live streaming, dan juga sound system diisi dengan anak muda GKI Tegalrejo yang sudah terjadwal. Gereja selalu mematuhi protokol kesehatan dengan menyediakan tempat cuci tangan untuk jemaat sebelum masuk untuk beribadah dan melakukan pengecekan suhu badan terlebih dahulu oleh jemaat yang telah ditentukan agar ibadah dapat berjalan dengan tenang tanpa khawatir.

Keempat, selain beribadah mingguan dan Pemahaman Alkitab yang diadakan setiap minggunya, tim pengabdian masyarakat juga memberi perhatian terhadap anakanak sekolah minggu yang mungkin belum paham betul mengenai pandemi Covid-19. Tim pengabdian masyarakat membuat sebuah program yang berisi video animasi untuk menjelaskan secara singkat mengenai (PHBS) Perilaku Hidup Bersih dan Sehat kepada anak-anak sekolah minggu yang mana video tersebut diunggah di Channel Youtube GKI Tegalrejo sehingga dapat diakses anak-anak sekolah minggu dengan mudah dari rumah masing-masing. Berikut merupakan penggalan gambar dari video PHBS.

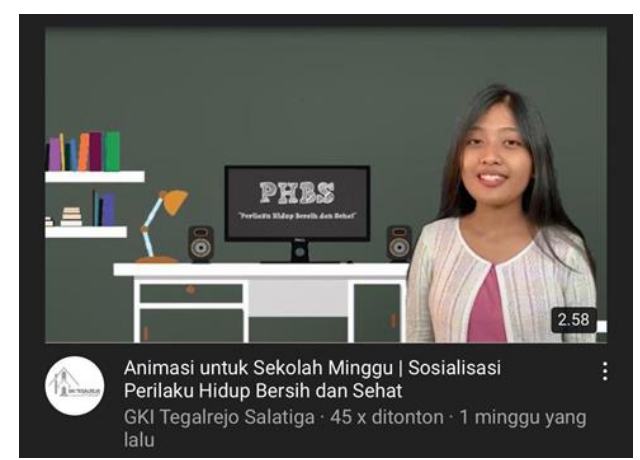

Gambar 2. Penggalan Video PHBS

Penerapan gereja menghadapi New Normal khususnya GKI Tegalrejo dapat terlaksana dengan baik sesuai dengan protokol kesehatan yang telah ditetapkan oleh pemerintah seperti sosial distancing, cuci tangan sebelum masuk beribadah, 
pengecekan suhu badan dan diwajibkan mengunakan masker ketika memasuki tempat ibadah serta menjaga jarak. Tim pengabdian masyarakat menganalisis hal tersebut menggunakan konsep SDGs tujuan ke-3 yaitu menjamin kehidupan yang sehat dan meningkatkan kesejahteraan seluruh penduduk semua usia, usia menengah ke bawah terkhususnya anak-anak sekolah minggu untuk menggugah kesadaran dalam menjaga kebersihan dan kesehatan. Oleh sebab itu, kelompok melakukan kegiatan atau program dalam membuat video animasi mengenai edukasi perilaku hidup bersih dan sehat (PHBS) yang berfokus pada anak-anak sekolah minggu itu sendiri.

Output dari pengabdian masyarakat ini yaitu Video PHBS dengan alamat link https://www.youtube.com/watch?v=UBMm_VNm_aI\&ab_channel=GKITegalrejoSa latiga dan tata cara pelaksanaan ibadah menghadapi New Normal sebagai berikut.

Bagan 1. Tata Cara Pelaksanaan Ibadah New Normal

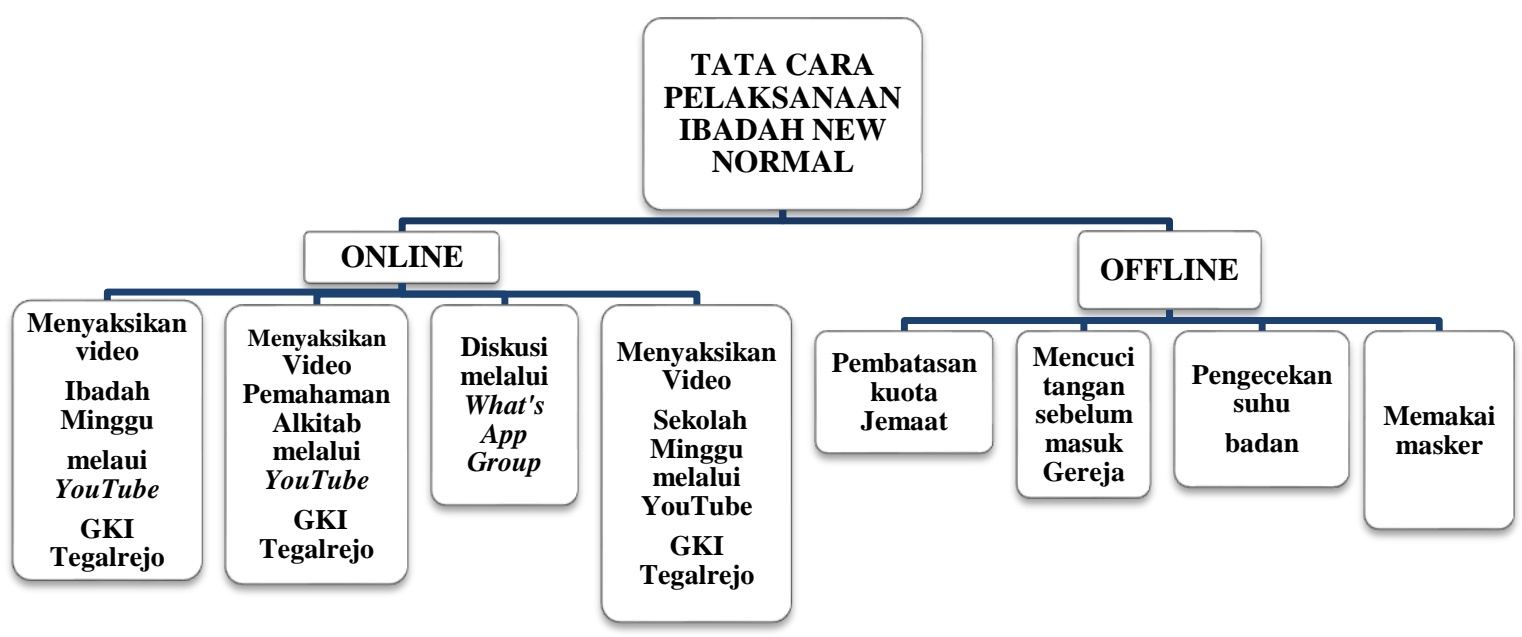

\section{SIMPULAN}

Dampak dari pengabdian masyarakat yang telah dilakukan yaitu peningkatan kapasitas anak-anak Sekolah Minggu tentang tata cara Perilaku Hidup Bersih dan Sehat. Peningkatan kapasitas pengurus GKI Tegalrejo tentang membuat tata cara pelaksanaan ibadah online maupun offline yang efektif dan sesuai protokol kesehatan yang benar. Produk yang dihasilkan dari pengabdian masyarakat ini adalah Video Pembelajaran PHBS yang telah diunggah pada YouTube Channel GKI Tegalrejo.

\section{DAFTAR PUSTAKA}

Hergianasari, P. (2020). View of Electoral Distancing: Alternatif Penyelenggaraan Pemilihan Kepala Daerah 2020 Ditengah Covid-19 Di Indonesia. Jurnal Magitrorum Et Scholarium, 1(1), 112-121. https://ejournal.uksw.edu/jms/article/view/4024/1510 Humas Setda, S. 2020. (2020). Salatiga Tanggap COVID-19 - Jangan Panik, Tetap 
Jaga Kesehatan. Humas Setda Salatiga. corona.salatiga.go.id

Kemenkes. (2020). https://promkes.kemkes.go.id/phbs. Kemenkes RI. https://promkes.kemkes.go.id/phbs

SDGs. (2018). Sustainable Development Goals. Sustainable Development Goals. https://www.sdg2030indonesia.org/\#modalIconDefinition

Sijabat, F., Sinuraya, E., Roos, C., \& Nainggolan, E. (2020). Peningkatan Kesehatan untuk Pencegahan COVID 19 di Gereja HKBP Pagaran Nauli Resort Medan Millenium Tahun 2020. Jurnal Abdimas Mutiara, 1(September), 76-85.

Ukim, K. K. N. P. P. M. (2020). PRODUK EDUKASI CEGAH COVID-19 HASIL KKN PKM DARING UKIM DI 3 KABUPATEN / KOTA DI MALUKU. 1(2), 163-178. 


\section{LAMPIRAN}

Foto Kegiatan Saat Pembuatan Tata Cara Pelaksanaan Ibadah
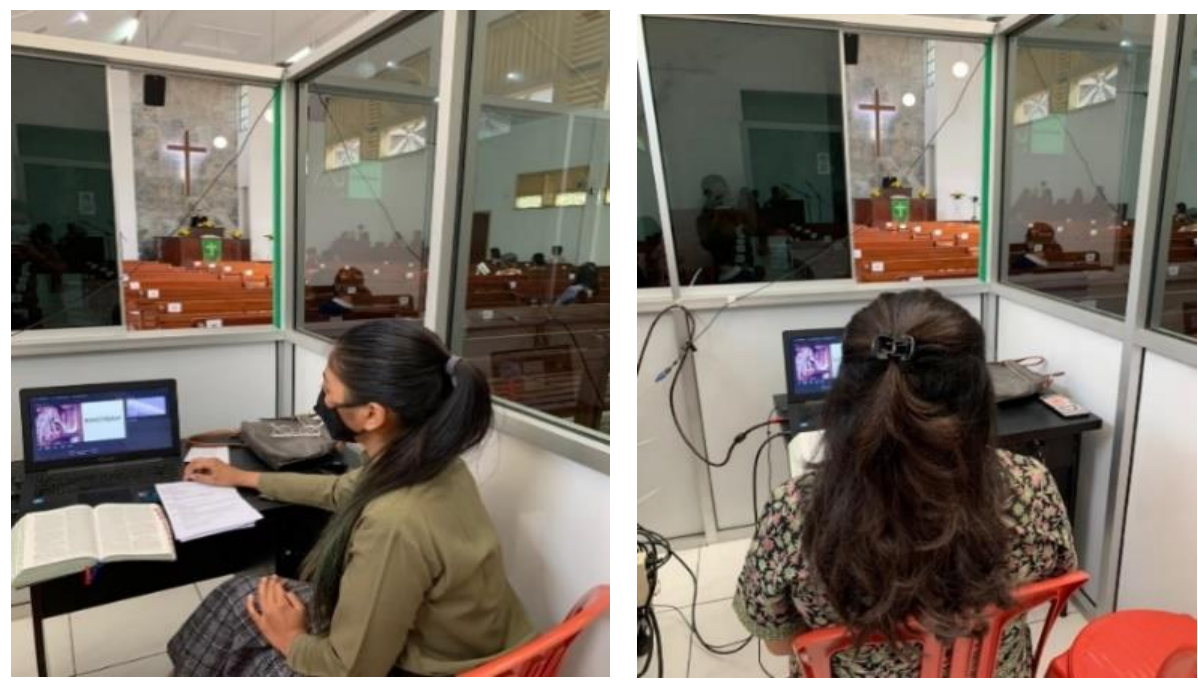

Foto Saat Pengambilan Video untuk Materi Ibadah Minggu
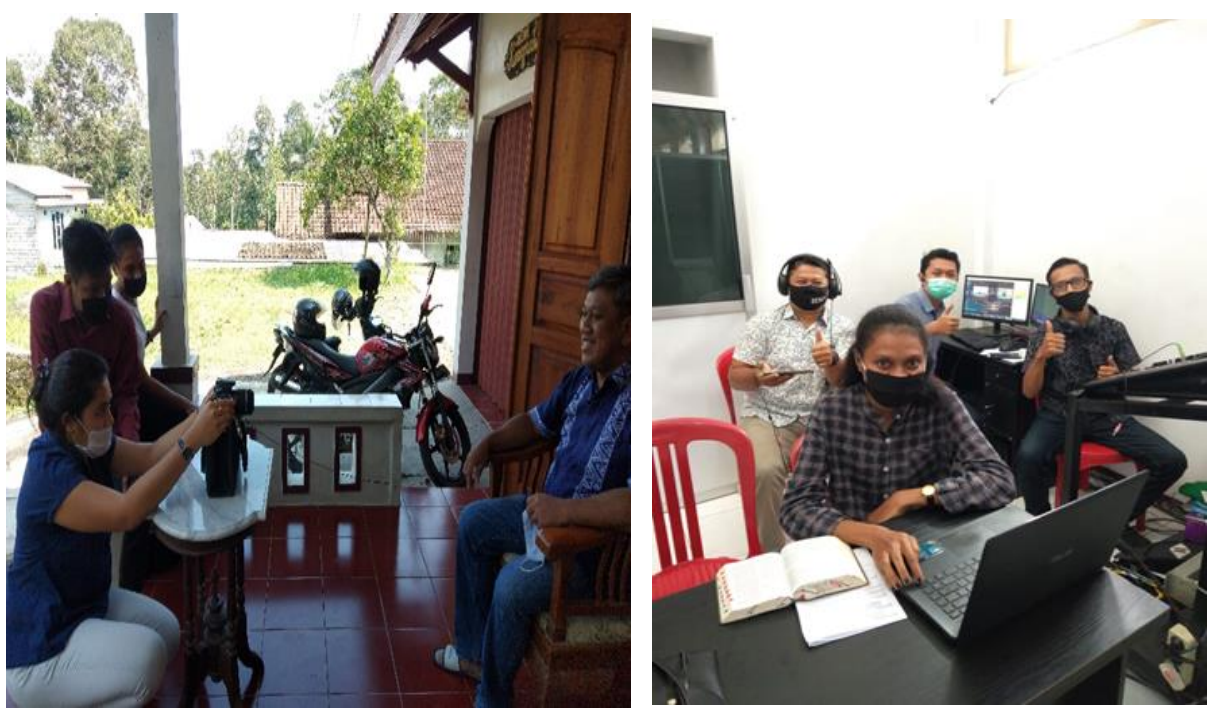
Foto Saat Pengambilan Video untuk Materi Pemahaman Alkitab
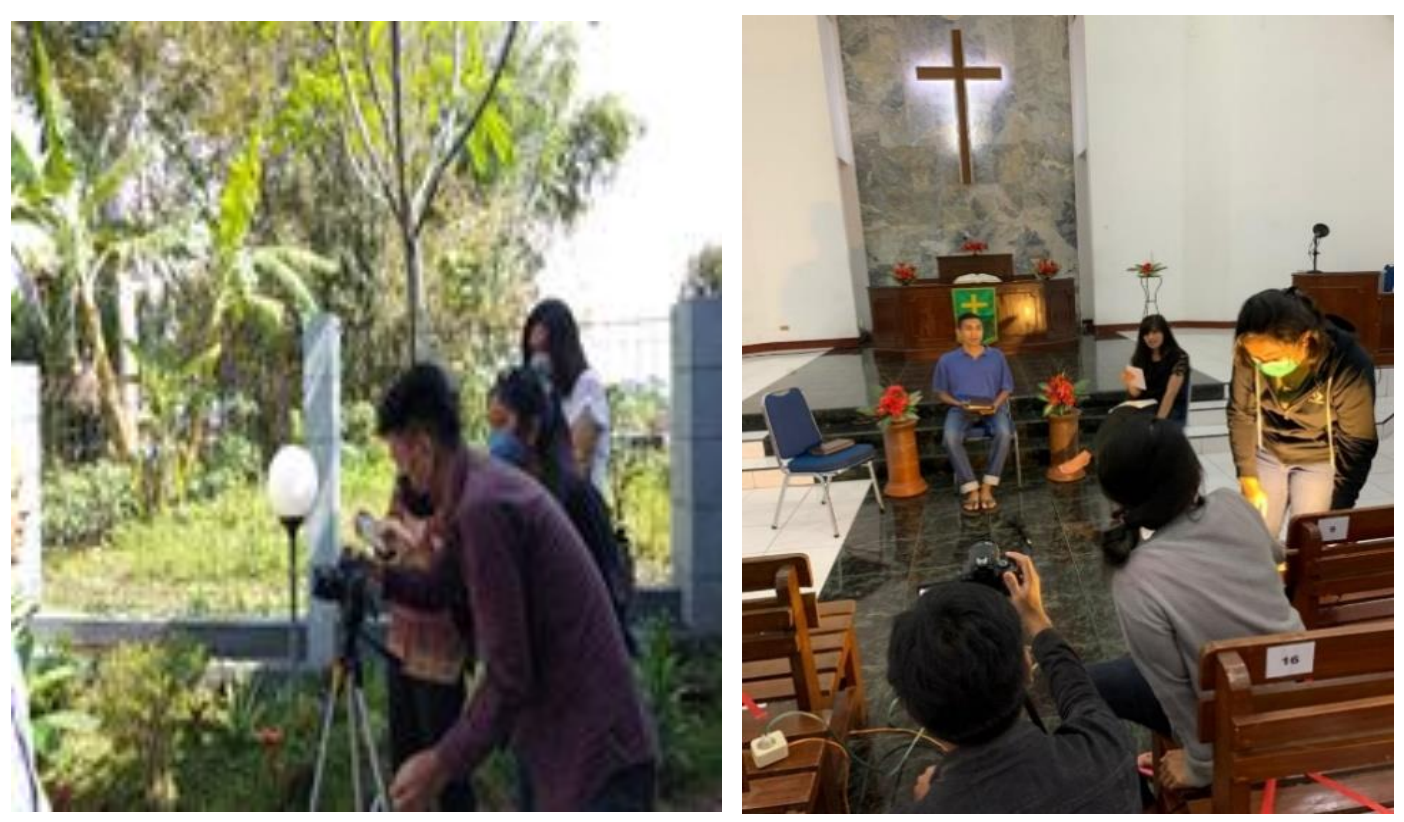